2022-01-20

\title{
Space and/or Time
}

\section{Sergeant, David}

http://hdl.handle.net/10026.1/18686

10.26597/mod.0180

Modernism/Modernity Print Plus

Project Muse

All content in PEARL is protected by copyright law. Author manuscripts are made available in accordance with publisher policies. Please cite only the published version using the details provided on the item record or document. In the absence of an open licence (e.g. Creative Commons), permissions for further reuse of content should be sought from the publisher or author. 


\section{Space and/or Time}

\section{By David Sergeant}

From its inception, much of the discussion around the terms realism and modernism stems from the fact that both are responses to a historically shifting conception of the "real," naming different procedures for representing it, with implicit and explicit claims as to their adequacy for doing so. This means that modernism can become either another iteration of what was called realism, or a renovation of it. As Joe Cleary puts it, in a special issue of $M L Q$ on "Peripheral Realisms," "modernism might now be viewed not as a liquidation but as an attempted sublation of realism into more spatially and cognitively expansive forms."1 Similarly, Dora Zhang has posited "a counterintuitive understanding of what we could call the hyperrealism of [Virginia] Woolf"s modernist aesthetics," because when "extended to its limit, realist verisimilitude tends not toward greater descriptive detail but toward the austerity of ostension, this being in fact the most precise way of describing."2 As Rachel Bowlby reminds us, Woolf was also the subject of the final chapter of Erich Auerbach's masterpiece Mimesis, with its subtitle "The Representation of Reality in Western Literature," and Woolf herself dismissed materialist writers such as Arnold Bennet for not being true to reality. ${ }^{3}$ In a complementary fashion, realism can be seen as modernism avant la lettre. Hence Fredric Jameson's formulation: "genuine realism, taken at the moment of its emergence, is a discovery process, which, with its emphasis on the new and the hitherto unreported, unrepresented, and unseen, and its notorious subversion of inherited ideas and genres (the Quijote!), is in fact itself a kind of modernism, if not the latter's first form."4 Or as David Cunningham summarizes it: "just as calls to some new realism have often appeared, historically, as themselves fundamentally modernist or avant-garde in form . . . equally it is the case that various of the most celebrated early twentieth-century discourses that seemingly 
demarcate modernism from 'realism' ... can also present themselves in the name of a more profound realism."5

To recognize this continuity is to shift emphasis from the equation of particular kinds of aesthetic form with realism or modernism, to the character of the historical moment to which those forms are responding, a shift that also informs Paul Stasi's observation, in the introduction to this forum, that realist and modernist aesthetic forms were defended or attacked by Theodor Adorno, Georg Lukács, Bertolt Brecht, Walter Benjamin, and Ernst Bloch, in their influential 1930s debates, according to their supposed timeliness and utility with respect to the same conception of modernity. Once this shift has taken place, the critical discussion of realism and/or modernism concerns as much the historical dynamics of modernity itself, as it does the attempt to periodize particular forms, styles, or techniques. Hence Nathan Brown's reperiodization of realism and modernism according to a modernity conceived of as coterminous with Marx's real subsumption, or Jameson's “experimental” and "therapeutic" proposal that the term "capitalism" be henceforth substituted "for modernity in all the contexts in which the latter appears." ${ }^{\prime 6}$ Hence, too, the possibility of considering the different historical paths that realism and modernism might take in the peripheries of the literary world-system, once modernity is conceived of "as a globally dispersed general 'situation'"- as the Warwick Research Collective puts it, following Jameson—-that "does not smooth away but rather produces unevenness, systematically and as a matter of course."7

\section{SPATIAL ISSUES AND HISTORY}

But if the question of "realism and/or modernism" is actually a question of history, what happens when we articulate this history in spatial terms, as we might reasonably do, given the 
connection between capitalist modernity and the rise of the nation, empire, and globalization? ${ }^{8}$ In what follows I want to briefly tease out one line of thought that follows from this question, taking my cues from the work of Jameson, which seems only appropriate, given that he remains so central a figure, either as pathfinder or as "Public Enemy No.1," in discussions of all these terms. ${ }^{9}$ The prominence that accrues to the spatial from the rise of globalization is perhaps most obvious in Jameson's original prescription for cognitive mapping, glossed by Carolyn Lesjak as "his version of a new realism." 10 Jameson wrote, in 1991, that "a model of political culture appropriate to our own situation will necessarily have to raise spatial issues as its fundamental organizing concern. I will therefore provisionally define the aesthetic of this new (and hypothetical) cultural form as an aesthetic of cognitive mapping." 11 More particularly, these spatial issues raise questions of scale, on the one hand, and of the relation between parts and whole, on the other: questions that are more acute for narrative - and politics - than for cartography, whose forms synthesize the two more readily. Their importance can be seen in Jameson's discussion of “the representation of a collectivity by individual characters" as being the core "issue" of the historical novel, and in his more recent equation of the totality with "collectivity," and the other, equally unsatisfactory names that collectivity has borne throughout history. ${ }^{12}$ The movement from individual to collective neatly captures both dynamics: parts instancing wholes as we move from one scale of representation to another.

The totality, then, concerns questions of scale and "spatial issues" — and as Cleary and Colleen Lye both observe, the concept of totality has been central to recent and historical evaluations of realism and modernism. ${ }^{13}$ However, this spatiality is itself, in these formulations, the very stuff of history, of temporality. Thus Lukács is, according to Jameson, "unhappy" for his "aspiration to totality" being taken for a desirable end-state, in a discussion 
that makes terms such as totality and collective more temporal than spatial, more diachronic than synchronic; the idea of the nation, for instance, is "only positive when emergent and still powerless" (Allegory, 195). In an earlier essay the same shift is made:

I believe that for Lukács totality was history, and that in reality (sic) his conception of realism had to do with an art whereby the narrative of individuals was somehow made to approach historical dynamics as such, was organized so as to reveal its relationship with a history in movement and a future on the point of emergence. Realism would thus have to do with the revelation of tendencies rather than with the portrayal of a state of affairs. (Jameson, "Antinomies of the Realism-Modernism Debate," 479) ${ }^{14}$

What I want to emphasize here is the way in which the spatial switches into the historical as soon as it is alighted on, and vice-versa. Of course, to observe that time and space are always inextricably entangled is unremarkable, but the distinctness with which the two are limned in Jameson's work helps bring out the vertiginous effect of this pairing, an effect more usually muted in criticism for the simple fact of it being taken for granted. But to encounter the collective and history in Jameson's writing can be like looking at Wittgenstein's duck-rabbit figure, in which the same picture flips between the two entities. You are looking at the spatial but then you are looking at the temporal, and though you know they are one and the same, you cannot quite see it as such. ${ }^{15}$ The vertiginous effect is heightened by this "history in movement" being tuned to what has not yet happened, "a future on the point of emergence," perhaps because the "portrayal of a state of affairs" implies something relatively static, compared to the transitional nature of "tendencies" (compare "aspiration" and "emergent," above). There is no looking at reality, it seems, without taking cognizance of what does not 
yet exist, because without this futural dimension historical time collapses into the "spatial logic of the simulacrum" that Jameson described in Postmodernism, coincident with "a society bereft of all historicity" (Postmodernism, 18). But to think about this historicity is to flip again, from the diachronic to the synchronic, because it is constituted by "the collective dimension" whose most obvious character is spatial and scalar: "the drama of the incorporation of individual characters into a greater totality, [that] can alone certify the presence of History as such" (Jameson, Antinomies, 267). Jameson's remark concerns the historical novel as a genre, but there is a suggestive overlap between this reading, from the chapter on the historical novel in Antinomies of Realism, and the account of modernism in $A$ Singular Modernity, particularly in the parallelism between their conclusions. The latter ends by asserting that "ontologies of the present demand archaeologies of the future, not forecasts of the past," while the former terminates with the claim that "our history, our historical past and our historical novels, must now also include our historical futures as well" (Singular Modernity, 215; Antinomies, 313).

This space/time dialectic drives Jameson's recovery of high modernism from Lukács's criticism of it: high modernism retains a narrative and, therefore, a historical capacity, notwithstanding its scanting of the nineteenth-century novelistic plot, because it possesses an orientation to the future, such that Ezra Pound and T. S. Eliot are "genuine modernists" because they "held to the Absolute and to Utopianism" — as is reflected, presumably, in their striving not only "after aesthetic totality" but also in their "systemic and Utopian metamorphosis of forms" (Singular Modernity, 168, 166). The demands of both scale (the totality, the collective) and narrative (historical change) are therefore met in authentic high modernism as they were in the authentic nineteenth-century realism of Lukács's accountand in a different way in Jameson's own account of that realism in The Antinomies of 
Realism, where "affect" brings a utopian spatial charge to the temporality of narrative, such that this realism manages to hold together, albeit with a tantalizing precariousness, the nineteenth-century "construction of the secular or bourgeois body" with the collective plot of history (Antinomies, 34). This antinomic account of nineteenth-century realism can then provide the germ for a longue durée periodizing narrative emergent from Jameson's other volumes, as Phillip Wegner has suggested, as the precariously yoked poles of the realist antinomy subsequently split apart into modernism (affect, existential present) and mass cultural forms (plot, temporality), before science fiction marks another periodizing break by emerging as "a form of realist (cognitive) modernism (estrangement), a unique dialectical third practice that subsumes aspects of both of the other two terms," estranging not through formal devices (as in modernism) but through its "realist" content whose "referent" is absent, as not actually existing. ${ }^{16}$ Such a reading would be supported by the final call at the conclusion of A Singular Modernity, for "archaeologies of the future" and "a wholesale displacement of the thematics of modernity by the desire called Utopia," which together provide the title to Jameson's next book: Archaeologies of the Future: the Desire Called Utopia and Other Science Fictions (Singular Modernity, 215).

\section{AN ORIENTATION TO THE FUTURE}

At its simplest, such a perspective on realism and/or modernism might be seen as emphasizing the obvious — but perhaps still too easily forgotten or occluded — truth that to consider realism and modernism is to also to consider the historical narrative you bring to those terms, as much as it is to consider actual instances of historical process or artistic work. However, the futural and utopian aspects of Jameson's reading might make this reminder more interesting for also suggesting ways in which such questions of space and time, of the 
totality and history, and indeed of realism and modernism, necessarily extend through our present moment and into the future. For instance, the questions of scale which shadow the notion of the totality or collective are only amplified by a climate emergency in which, as Timothy Clark puts it, "a campaign for environmental reform in one country may be already effectively negated by the lack of such measures on the other side of the world . . . a sentence about the possible collapse of civilization can end, no less solemnly, with the injunction never to fill the kettle more than necessary when making tea." ${ }^{, 17}$ In the light of this and other disconnects, the contemporary critical discourse of "planetarity" proposes a reconfiguration of the scalar relationship that has characterized globalization and post-World War Two history, such that the economic becomes ecological, the hierarchical and homogenous becomes relational and dialogic, and so on. ${ }^{18}$ On the one hand, this reconfiguration could be seen as a kind of utopian "archaeology of the future" that simultaneously reaches back to discussions of realism and modernism: the positing of more equitable and effective planetary relationships "on the point of emergence" altering how we see the "historical dynamics" that might now appear to lead up to them. Rather than the tiger's leap into the past that Benjamin famously wrote of, it is a leap into the future, to construct a vision that would work, in our penumbral age of permanent eclipse, like Benjamin's sun: “as flowers turn toward the sun, what has been strives to turn — by dint of a secret heliotropism — toward that sun which is rising in the sky of history." 19 On the other hand, however, the focus on scale might beg the question, in light of the discussion so far, as to how exactly such new spatial forms can gain historical purchase, and become more than an abstract and well-intentioned aspiration.

Similarly, a self-consciousness about the entanglement of space and time in the shadow of the Anthropocene might bear on Susan Stanford Friedman's positing of “planetary modernisms," and her wish to replace Jameson's famous injunction "always historicize!” with "always 
spatialize!" ${ }^{20}$ Modernism becomes, in Friedman's account, any period characterized by "sharpened change, radical ruptures, accelerated mobilities," (Planetary, 318) with "the category empire" the glue that holds these identifications together, as "the necessary descriptor ... of the complex politics, intercultural ferment, and dystopic violence/utopian possibilities of recurrent modernities across the longue durée of time and global spaces". ${ }^{21}$ However, parsed via the space/time grammar sketched above, this identification of different modernisms throughout history acts rather like the bringing together of different stars in a constellation, such that each gains its identity via its formal relation to the others, and the different history possessed by each one-indeed, in this analogy, literally the different times from which they emerged - is left behind. Such "recurrent" forms slip away from history, or at least from the history of secular modernity, and the problematic nature of this becomes only more evident in the midst of an ecological emergency whose historical trajectory is frighteningly exceptional, accruing changes from which there will be no cyclical return. This emergency demands an attention to something like the entire globe- - the planet as collective - and so its spatial dimension, its geographic extent and organization, are obviously crucial. However, it requires that we think about how distinct histories are legible in discrete spaces, so that the long history of capitalist modernity is understood as a record of "combined and uneven development," while at the same time demanding a cognizance of the possibility of the new, of the utopian break, as it might be read into and out of such histories. ${ }^{22}$ As Lauren Goodlad observes, reading and quoting Jameson, "the antinomies of any historical literature concern persistent tensions 'between sociology and history,' 'between structure and the event,' between 'cultural continuities' and the emergence of the new-and, from a formal standpoint, between 'a narrative of individuals" and 'historical dynamics as such"” (Victorian Geopolitical, 281). Such antinomies account for much of the difficulty in 
thinking about both the current crisis as well as questions of "realism and/or modernism," even as they continue to be the ground for any such thought.

${ }^{1}$ Joe Cleary, "Realism after Modernism and the Literary World System," Modern Language Quarterly 73, no. 3 (2012): 255-68, 261.

${ }^{2}$ Dora Zhang, "Naming the Indescribable: Woolf, Russell, James, and the Limits of Description," New Literary History 45, no 1, (2014): 51-70, 65.

${ }^{3}$ Rachel Bowlby, 'Foreword', in Adventures in Realism, ed. Matthew Beaumont, (London: Blackwell, 2007): xi-xviii, xvi.

${ }^{4}$ Fredric Jameson, "Antinomies of the Realism-Modernism Debate," Modern Language Quarterly 73, no. 3 (2012): 475-85, 476. See also Nathan Brown's recent assertion that "realism is the death of romanticism, and that at the same stroke it is, in its self-recognition as an -ism, the birth of modernism" ("Postmodernity, not yet: toward a new periodisation," Radical Philosophy 2, no. 1 (2018): 11-27, 24).

${ }^{5}$ David Cunningham, "Time, Modernism, and the Contemporaneity of Realism," in The Contemporaneity of Modernism: Literature, Media, Culture, ed. Michael D'Arcy and Mathias Nilges, (London: Routledge, 2015): 49-62, 60n6.

${ }^{6}$ See Brown, "Postmodernity, Not Yet;" Fredric Jameson, A Singular Modernity (London: Verso, 2002), 215.

${ }^{7}$ WReC (Warwick Research Collective), Combined and Uneven Development: Towards a New Theory of World-Literature (Liverpool: Liverpool University Press, 2015), 12. See also the special issues: "Peripheral Realism," ed. Joe Cleary, Jed Esty, and Colleen Lye, Modern Language Quarterly 73, no. 3 (2012); "Worlding Realisms," ed. Lauren M. E. Goodlad, Novel: A Forum on Fiction 49, no. 2 (2016).

${ }^{8}$ See Lauren M. E. Goodlad's The Victorian Geopolitical Aesthetic: Realism, Sovereignty, and Transnational Experience (Oxford: Oxford University Press, 2015) for the geopolitical dimensions of Victorian realism, contra Jameson's equation of it with the nation; and WReC's Combined and Uneven Development for the claim that the temporal parameters of "modernism" need to be set back "to incorporate the great wave of writing from the midnineteenth century onwards that is construable precisely ... as an encoding of the capitalisation of the world" (17-18).

${ }^{9}$ The quoted label is Stephen Ross's - though he is not in agreement with it (see "Provocations on the Philosophy of Weakness," in "Responses to the Special Issue on Weak Theory, Part IV," Modernism/Modernity Print Plus).

${ }^{10}$ Quoted in Colleen Lye, “Afterword: Realism's Futures," Novel: A Forum on Fiction 49, no. 2 (2016): 343-57, 344.

${ }^{11}$ Fredric Jameson, Postmodernism, or, The Cultural Logic of Late Capitalism (Durham, NC: Duke University Press, 1991), 51.

${ }^{12}$ Fredric Jameson, The Antinomies of Realism (London: Verso, 2013), 282; Jameson, Allegory and Ideology (London: Verso, 2019), 194-95.

${ }^{13}$ See Cleary, "Realism after Modernism," 268; Colleen Lye, "Afterword," 344.

14 The "sic" is Jameson's!

15 This might conceivably serve as an impressionistic description of the dialectic, the critical operation so central to Jameson's method — which has been nicely described by Christopher Prendergast, in his reading of A Singular Modernity, as “akin to Mallarmé's Absolute, 
floating in a zone of virtuality that is neither presence nor absence . . less a state than a process of thought" ("Codeword Modernity," New Left Review 24 (2003): 95-111, 110). ${ }^{16}$ Philip E. Wegner, Shockwaves of Possibility: Essays on Science Fiction, Globalization, and Utopia (Bern: Peter Lang, 2014), 13.

${ }^{17}$ Timothy Clark, 'Scale: Derangements of Scale' in Tom Cohen ed., Telemorphosis: Theory in the Era of Climate Change, Vol. 1 (Open Humanities Press, 2012): 148-66, 151.

${ }^{18}$ An exemplary account is the introduction by Amy J. Elias and Christian Moraru's introduction to The Planetary Turn: Relationality and Geoaesthetics in the Twenty-First Century (Evanston, IL: Northwestern University Press, 2015), xi-xxxvi.

${ }^{19}$ Walter Benjamin, "On the Concept of History," trans. Harry Zohn, in Selected Writings, Vol. 4: 1938-40, ed. Howard Eiland and Michael W. Jennings, (Cambridge MA: Harvard University Press, 2003), 389-400, 390.

${ }^{20}$ Susan Stanford Friedman, Planetary Modernisms: Provocations on Modernity across Time (New York: Columbia University Press, 2015), 84.

${ }^{21}$ Susan Stanford Friedman, "Provisionally Present" in "Responses to the Special Issue on Weak Theory, Part III," M/M Print Plus.

${ }^{22}$ See WReC, Combined and Uneven Development. 